\title{
State Legislatures as National Actors
}

\author{
Shanna Rose, Claremont McKenna College
}

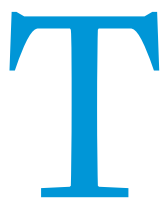
he role of state legislatures in national affairs has become both more prominent and more conflictual in recent years. Due to various political forces-partisan polarization, the Trump presidency, Republican gains in Congress beginning in 2010, congressional gridlock, and growing overlap in federal and state spheres of authority-blue states are resisting federal policies in arenas such as immigration, tax reform, and marijuana as well as filling in the vacuum left by federal inaction on progressive priorities such as the minimum wage and gun control. Meanwhile, red states are increasingly preempting blue-city policies-ranging from antidiscrimination to environmental laws-with the effect of shoring up the GOP's policy agenda. ${ }^{1}$

Republican control of national government has contributed to a dramatic realignment of partisan positions on matters of federalism in recent years (Goelzhauser and Rose 2017). Although the GOP traditionally championed states' rights, the Trump administration has sought to impose wideranging national policies that implicate the states, from stricter enforcement of federal law against the use of marijuana to executive orders restricting immigration. Meanwhile, Democrats-long champions of federal policy interventionhaving lost control of the national government, concluded "they have no alternative but to redouble their efforts at the local level" (Rosen 2016). Although "progressive federalism" had long been an oxymoron, at least since the New Deal, the Trump era seems to have prompted a liberal reawakening to the advantages of localism as a tool for resisting the encroachments of an assertive national government.

Disputes between the national government and the states are hardly new. Examples of what Bulman-Pozen and Gerken (2009) refer to as "uncooperative federalism" abound, dating back to the nation's founding. Tensions mounted throughout the twentieth century as federal policy expanded and increasingly implicated the states. The New Deal and Great Society in particular ushered in an intrusive new set of regulations and grant-in-aid conditions, and state officials often resented the burdens they imposed. And of course Southern states frequently were sharply at odds with the federal government during the civil rights era.

By contesting federal intervention, states shaped various national policies during the twentieth century, from resisting unemployment-insurance reform in the 1940s (Karch and Rose 2017) to pushing for welfare reform in the 1990 s (Bulman-Pozen and Gerken 2009). Uncooperative federalism is possible, in part, due to the limits of federal regulatory capacity, which puts the states in a position of power. "When Congress makes a law, it often lacks the resources to enforce it. Instead, it relies on states and localities to carry out its policies....This means that states can shape policy simply by refusing to partner with the federal government" (Gerken and Revesz 2017). Moreover, as the number of federal-state policies expanded, so has the states' administrative role, augmenting their resources, expertise, and capacity for resistance.

Although intergovernmental relations have long been contentious, both the number and the intensity of conflicts have escalated in recent years, as state officials began to resist federal policy intervention with mounting force (Gamkhar and Pickerill 2012). This trend can be traced to the rise of partisan polarization and, with it, "partisan federalism"-that is, "political actors' use of state and federal governments in ways that articulate, stage, and amplify competition between the political parties" (Bulman-Pozen 2014). With the GOP controlling a majority of state governments, resistance largely reflects the efforts of a few blue states. ${ }^{2}$

Some of the most intense federal-state skirmishes center on immigration policy. In response to the Trump administration's expanded deportation orders, California passed a law declaring itself a sanctuary state, effective January 2018. The law-similar to those passed by several cities-limits the cooperation of state and local law enforcement with federal immigration authorities. Although California's policy is the most comprehensive in the country, other states-including Connecticut, Illinois, Rhode Island, Vermont, and Washingtonalso passed laws limiting local police cooperation with federal immigration agents. The Trump administration's efforts to combat state and local resistance-including an executive order threatening to "[e]nsure that jurisdictions that fail to comply with applicable Federal [immigration] law do not receive Federal funds, except as mandated by law" (Executive Order 13768) and a request for an injunction against California's sanctuary-state law-thus far have been stymied in the courts.

Tax policy is another prominent federal-state battlefield. In 2018, several state legislatures passed laws designed to circumvent a provision of the Tax Cuts and Jobs Act of 2017 that caps state and local tax (SALT) deductions at \$10,0oo. The measure disproportionately affects Northeastern and Western states with high property values-states that also tend to lean Democratic. Several of these states-including Connecticut, Oregon, New Jersey, and New York-responded by enacting creative workarounds enabling taxpayers to sidestep the SALT cap. The most common variant establishes government-linked "charitable" funds to which taxpayers can make contributions in exchange for an offsetting tax credit. The Trump administration responded with new regulations 
preventing attempts to convert tax payments into charitable contributions. The new rules appear to be temporarily discouraging taxpayers from using charitable tax deductions to evade the cap; however, with litigation pending, it remains to be seen whether the states or the Trump administration ultimately will prevail (Jones 2018).

State legislatures also sought to reverse various other federal actions in policy arenas such as marijuana, health care, and net neutrality. Notwithstanding the Trump administration's rescission of Obama's hands-off marijuana policy with respect to the states, Vermont became the ninth stand your ground measures and policies allowing guns in $\mathrm{K}-12$ schools.

In addition to these varieties of resistance and activism, state legislatures are playing a third major role in shaping national policy through the preemption of local laws. As progressive cities pass laws that defy the Trump administration's agenda, red states are passing sweeping measures designed to restrict cities' authority. This dynamic reflects not only unprecedented GOP control of state capitals but also the "big sort" of liberal voters to cities and conservatives to rural and suburban areas-putting blue cities and red states on a

\section{Although intergovernmental relations have long been contentious, both the number and the intensity of conflicts have escalated in recent years, as state officials began to resist federal policy intervention with mounting force (Gamkhar and Pickerill 2012).}

state to legalize recreational use of the drug-and the first to do so through the legislative process. Following passage of the Tax Cuts and Jobs Act of 2017, which eliminated the Affordable Care Act's penalty for not having health insurance, New Jersey passed a law imposing an individual health-insurance mandate at the state level; several other states considered following suit. In response to the Trump administration's reversal of the Obama administration's netneutrality regulation, several states enacted net-neutrality laws that achieve the goals of the rescinded Federal Communications Commission regulation (Rose and Goelzhauser 2018).

In addition to resisting federal policies, blue-state legislatures also filled the policy vacuum in areas in which federal lawmakers have refused to act, such as the minimum wage and gun control. The federal minimum wage of $\$ 7.25$ has not changed since 2009; despite broad popular support for an increase, legislation to raise it has stalled repeatedly in Congress. Stepping into the void, a majority of states passed legislation or ballot initiatives raising the minimum wage above $\$ 7.25$-and, in some cases, such as California and Massachusetts, as high as $\$ 15$ an hour (phasing in gradually over several years). Although such policies have been adopted predominantly by blue states, a few red states (e.g., West Virginia and South Dakota) have followed suit. Several progressive cities have passed similar measures but have been stymied by conservative state lawmakers.

State legislatures also filled a federal policy vacuum in gun control. Following the Parkland and Las Vegas mass shootings, dozens of states passed gun-control measures against a backdrop of federal inaction. Several states banned bump stocks and high-capacity magazines, raised the minimum age to buy a gun to 21, or adopted "red flag" laws allowing police to temporarily confiscate firearms from potentially dangerous people. Most of these policies cropped up in blue states, but a few have passed in red states (e.g., Florida). Conversely, several red states voted down similar gun-control policies or adopted policies enhancing gun rights, including so-called collision course. In addition, it reflects the growing activism of powerful interest groups such as the American Legislative Exchange Council and the Association of Chamber of Commerce Executives in propagating conservative, businessfriendly preemption laws.

State preemption of local laws is not a new phenomenon. Indeed, the recent wave of preemption laws bears "striking resemblance to city-state dynamics during the middle of the nineteenth century, an era marked by flagrant state interference in local affairs" (Kogan 2018). Nonetheless, there has been a precipitous rise in the number of preemption laws in recent years (National League of Cities 2018).

Recent preemption laws are not only more numerous but also substantively distinct from previous preemption laws. Traditionally, state governments typically used preemption laws to set minimum standards-or a "floor"-for local responsibilities. By contrast, recent laws tend to be "maximum preemptions" forbidding localities from passing laws or regulations in specific policy areas (Riverstone-Newell 2017). Preemption laws also have become more coercive and punitive; for example, they increasingly include provisions designed to hold local governments fiscally accountable or to remove local government officials from office for preemption violations (Phillips 2017). Finally, modern preemption laws are distinctive as a result of "the national salience of the issues at stake and the clear ideological dimension that underpins many of these conflicts" (Kogan 2018).

Examples of state preemption of local laws abound. Among the most common targets of state preemption laws are local minimum-wage and sick-leave ordinances. For instance, in 2015, St. Louis passed an ordinance to gradually increase the city's minimum wage: it rose to $\$ 10$ per hour in 2017 and was set to rise to $\$ 11$ per hour in 2018 . However, shortly after the policy went into effect, Missouri's Republicancontrolled General Assembly passed a law capping the minimum wage at $\$ 7.70$ statewide. As of 2018, 28 states had adopted laws preempting local wage regulations and 23 had passed laws restricting local paid sick-, family-, and medical-leave 
laws, typically on the grounds that a "patchwork" of different regulations is bad for business (National League of Cities 2018).

State preemption of local antidiscrimination laws, although less common than preemption of wage laws, has been the source of considerable intergovernmental tension and the subject of extensive media coverage. In the most high-profile case, North Carolina's Republican-controlled General Assembly in 2016 overturned a Charlotte ordinance banning discrimination against lesbians, gays, bisexuals, and transgender the widespread adoption of home-rule provisions for at least some localities, typically allow their states to curtail the regulatory authority of their local governments" (Briffault 2018, 2008). State supreme courts have struck down various local ordinances-including plastic-bag bans in Texas and firearm regulations in Arizona-concluding that those policies are preempted by state law. There are exceptions, however, such as the 2018 Missouri Supreme Court ruling that St. Louis had acted within its charter authority when it approved an increase in the minimum wage.

\section{As progressive cities pass laws that defy the Trump administration's agenda, red states are passing sweeping measures designed to restrict cities' authority.}

(LGBT) people, which-among other things-had allowed transgender individuals to use the restroom corresponding with their gender identity. ${ }^{3}$ The law, HB2, also prohibited every city in the state from passing LGBT nondiscrimination ordinances. Public outcry and costly boycotts led the state legislature to partially repeal the so-called bathroom law while retaining state control over bathroom-access regulations and enacting a moratorium on local antidiscrimination ordinances until 2020.

Additional targets of state preemption laws include environmental and immigration policies, among others. Hundreds of localities have prohibited hydraulic fracturing (i.e., "fracking") within their jurisdictions, citing potential environmental and health risks, only to have their state legislatures-typically under pressure from the oil and gas industry-preempt the regulations (Riverstone-Newell 2017). States also have passed laws prohibiting localities from banning plastic grocery bags, restricting the sale of sugary drinks, establishing sanctuary cities, and enacting firearm regulations. Although most preemptive laws are passed by red states targeting blue cities, there also are exceptions. For instance, occasionally a blue state preempts a bluer city, such as when New York State preempted New York City's plastic-bag ordinance (Bulman-Pozen 2018).

These preemption laws target a single policy area, such as gun control or immigration. Another type of preemption lawthe so-called blanket preemption law-also is becoming more common. Such laws seek to prohibit localities from adopting any policy that does not exactly conform to state law. In such cases, the state seeks to "command the field" in which "the field" encompasses all state laws, as opposed to a single policy area (Riverstone-Newell 2017, 418). For instance, in 2016, Arizona's General Assembly passed a law-"the mother of all local preemption bills"-that withholds funding from any local government that passes a regulation that the attorney general determines "violates state law or the constitution of Arizona" (Daigneau 2017).

When preemption cases go to court, existing legal doctrines favor the states, which typically prevail. "Federal constitutional law treats state-local relations as almost entirely a matter for the states. State constitutions, despite
As American intergovernmental relations grow increasingly uncooperative and partisan, state legislatures have emerged as pivotal players in national affairs. Blue states are, by turns, resisting federal policy initiatives and taking initiative where federal policy is gridlocked; red states are shutting down blue cities' efforts to do the same. Policy debates that previously played out primarily on the national stage are increasingly devolving to state capitols, resulting in a patchwork of policies and an increasingly fragmented federalism. .

\section{NOTES}

1. Of course, state legislatures are only one such set of actors caught up in this tense triangular relationship-others include governors, attorneys general, and voters themselves through direct democracy.

2. However, occasionally state resistance reflects a bipartisan rejection of federal policy. For instance, coastal states are virtually unanimous in opposing the Trump administration's attempts to expand offshore drilling.

3. Two red states previously passed similar preemption laws: Tennessee in 2011 and Arkansas in 2015.

\section{REFERENCES}

Briffault, Richard. 2018. “The Challenge of the New Preemption." Stanford Law Review 70: 1995-2027.

Bulman-Pozen, Jessica. 2014. "Partisan Federalism." Harvard Law Review 127 (4): 1077-146.

Bulman-Pozen, Jessica. 2018. "State-Local Preemption: Parties, Interest Groups, and Overlapping Government." PS: Political Science \& Politics 51 (1): 27-28.

Bulman-Pozen, Jessica, and Heather K. Gerken. 2009. "Uncooperative Federalism." Yale Law Review 118 (7): 1256-310.

Daigneau, Elizabeth. 2017. "Will States Stop Cities from Combating Climate Change?" Governing, January.

Gamkhar, Shama, and J. Mitchell Pickerill. 2012. "The State of American Federalism 2011-2012: A Fend for Yourself and Activist Form of Bottom-Up Federalism." Publius: The Journal of Federalism 42 (3): 357-86.

Gerken, Heather K., and Joshua Revesz. 2017. "Progressive Federalism: A User's Guide." Democracy 44 (Spring). Available at https://democracyjournal.org/ magazine/44/progressive-federalism-a-users-guide.

Goelzhauser, Greg, and Shanna Rose. 2017. "The State of American Federalism 2016-2017: Policy Reversals and Partisan Perspectives on Intergovernmental Relations." Publius: The Journal of Federalism 47 (3): 285-313.

Jones, Paul. 2018. "IRS Notice Expected to Slow States' SALT Workarounds." Tax Notes, June 5. Available at www.taxnotes.com/editors-pick/irs-noticeexpected-slow-states-salt-workarounds. 
Karch, Andrew, and Shanna Rose. 2017. "States as Stakeholders: Federalism, Policy Feedback, and Government Elites." Studies in American Political Development 31 (1): 47-67.

Kogan, Vladimir. 2018. "Means, Motives, and Opportunities in the New Preemption Wars.” PS: Political Science \& Politics 51 (1) 28-29.

National League of Cities. 2018. "City Rights in an Era of Preemption A State-by-State Analysis-2018 Update.” Available at www.nlc.org/ resource/city-rights-in-an-era-of-preemption-a-state-by-state-analysis.
Phillips, Lauren E. 2017. "Impeding Innovation: State Preemption of Progressive Local Regulations." Columbia Law Review 117 (8): 2225-63.

Riverstone-Newell, Lori. 2017. "The Rise of State Preemption Laws in Response to Local Policy Innovation." Publius: The Journal of Federalism 47 (3): 403-25.

Rose, Shanna, and Greg Goelzhauser. 2018. "The State of American Federalism 2017-2018: Unilateral Executive Action, Regulatory Rollback, and State Resistance." Publius: The Journal of Federalism 48 (3): 319-44.

Rosen, Jeffrey. 2016. “States' Rights for the Left.” New York Times, December 3. 